\title{
Measuring Efficiency of Using Resource in the Production Process of Making Stamped-Batik: A DEA Approach
}

\author{
Aries Susanty \\ Sri Hartini \\ Diana Puspitasari \\ Pramudi Arsiwi \\ Department of Industrial Engineering, Diponegoro University, Campus Tembalang, Semarang \\ ariessusanty@gmail.com
}

\author{
Doi:10.5901/mjss.2015.v6n5s2p318
}

\begin{abstract}
One of mathematical modelling to assess relative efficiencies of the group of the decision making unit in production systems is Data Envelopment Analysis (DEA). In this study, we use DEA to assess relative efficiencies in the production process of making stamped batik of 16 SMEs which is located in Pekalongan, Solo, and Yogyakarta. The general conclusion that there is a variance of efficiency among the SMEs, indicating some SMEs has misallocation or inefficient of application of using worker, mori, wax, dyestuff, water, and fuel in the production process of making stamped batik. Additionally, this study provides output target values for improving the efficiency. Overall, this study gives confirmation of how the DEA approach as the advances and recent development in efficiency analysis can be applied for an effective evaluation of performance in SMEs stamped Batik.
\end{abstract}

Keywords: Data Envelopment Analysis' Efficiency; Stamped Batik; Pekalongan; Solo; Yogyakarta

\section{Introduction}

One of very famous and important textile products from Indonesia is batik. Batik made from Javanese. As a traditional and cultural heritage in Indonesia, batik has a very long historical path (Hasanudin, 2001). The word of batik derives from Javanese language, i. e. "mbatik ( $m b a t$ and tik)". In Javanese language, the word of "mbaf" also recognized as ngembat. The meaning of word ngembat is brought up or throw and the meaning of word tik is a point. So, based on the meaning of two words, the meaning of mbatik is throwing the point several times on the fabrics (Anwar et al, 2013). Batik is produced by dipping the fabric in the dye solution. One of the main raw material uses in the process of making batik is wax. This material is used to create patterns and design. There were two purposes of applying wax into the fabric. First, applying wax into the fabric will be prevent some of the areas of fabric absorbing the colors when the material is plunged into a bath containing the dye. The applied wax resists dyes and therefore allows the artisan to color selectively by soaking the cloth in one color, removing the wax with boiling water, and repeating if multiple colors are wanted. The other purpose is controlling the color from spreading out from a specific region when the color is painted so that would be obtained certain motif in the fabric (Oripande, 2012). Based on the process of making batik, there were two types of batik. i. e "batik-tulis" (hand-drawn batik) and "batik cap" (hand stamped batik). Hand-stamped batik is resulted from the revolutionizing of the process of making batik. Hand-stamped batik was developed by the Javanese in the middle of the 19 the century. The hand-drawn batik uses a traditional tool called canting to paint the wax into the fabric; whereas, hand-stamped batik use copper stamp to stamp the wax into the fabric. The more creative design can be resulted from the combination of the canting and the copper stamp (Gunaryo, et al, 2008). This study chosen batik as an object the research because the batik industry has a vital position in Indonesia and since October 2011, batik has been accepted by the United Nations Educational, Scientific, and Cultural Organization (UNESCO) as "Intangible World Heritage" (Meutia, 2013). Batik is produced by many areas in Indonesia and Java is an area that produces the largest batik. This industry can absorb an extensive number of workers and generates a significant export value. According to the Ministry of Industry and Trade, there were 39,600 business units that produce batik in 2011 and that business units can absorb 165,000 workers. At 2011, export value generated by the batik industries reached IDR 4 million and supplies of batik raw material value reached IDR 1.8 trillion (Iriani \& Priyanto, 2013). 
The vital position of batik industries is contradictory with the capacity of their management and production. There are various issues confronted by SMEs in batik industry, such as limitation of capital, limitation of equipment, limitation of natural dyes sourcing, limitation of advertising, limitation of relationship with higher education, private sector, and government, and limitation of management. A few studies likewise demonstrated that the result from the execution of the batik business are still unsteady (Meutia, 2013). Economically, invest in the batik industry less attractive to investors who require a fast return because the nature of this industry, which is needed long production time and can't quickly follow the current fashion (Hayati, 2007; Aribawa, 2009). According to Aribawa (2009), the limitation of batik industry to keep an eye on the current fashion such as garment industry is one of the factors that cause the slow development of this industry in District of Pancur, Lasem, Rembang. Another issue confronted by batik industry is a limitation of the motif of batik (a decorative design or pattern) which had been patented in Indonesia. Only $10 \%$ of the motif of batik had been patented in Indonesia. This condition causes the batik motifs derived from Indonesia is vulnerable to product piracy and at the moment, many batik motifs from Indonesia has been patented in Malaysia (Budiono \& Vincent, 2010). The other source of threat to the batik industry is coming from China. Nowadays, China flooded batik markets in Indonesia with cheaper "batik textile". Batik textile" industry have some advantages. "Batik textile" can be produced quickly because they produce by engine and also capable to keep an eye with the worldwide pattern; whereas, the traditional batik industry takes a longer time to produce and traditional batik only produces based on local designs. The implementation of AFTAChina in the year 2015 will increase the challenges faced by the batik industry. In this case, AFTA-China in the year 2015 will expand the power of rivalry because the attack of batik imports from other ASEAN nations, especially the attack that comes from China region (Darmansyah \& Soebagyo, 2010).

Related to process of making batik, this process has been associated with inefficiency because of material-usage. This inefficiency can lead to high cost of production and large volume of waste generated from the raw materials, additive, and the production process. Furthermore, the increase in the volume of waste will also cause economic loss and a negative effect on the environment. The economic losses caused by the need for additional waste treatment. Nurdalia (2006) found that the significant inefficiency is related to the usage of wax, dyestuff and water. The portion of wax and dyestuff cost dominate the total production cost of three companies that the author researched. Unreusable wax reached $60 \%$, dyestuff losses from $0.07 \%$ a year until $54.58 \%$ a year, and water inefficiency approximately reached $80 \%$ a year. Based on this condition, it is important to identify the sources of inefficiency, measure it accurately, and understand how to fix the inefficiency. This study aims to assess relative efficiencies the production process of making stamped-batik of 16 SMEs which is located in Pekalongan, Solo, and Yogyakarta. More specifically, this study aims to identify the level of efficiency of using mori, dyestuff, wax, water, and fuel in the production process of making stamped batik; measure and compare the level of efficiency of several SMEs stamped-batik which became a sample of this study; and provides some suggestions and output target values for improving the efficiency. The result of measurement of the efficiency gains from several SMEs stamped-batik will provide the SMEs supplementary information about their non-financial performance indicators, since this measurement will consider all factors which have been contributed to the non-financial performance

Data Envelopment Analysis (DEA) is a fundamental tool and also one of the mathematical approaches for measuring the efficiency gains. DEA is known as a linear programming model. On the basis of the work of Farrell (Farrell, 1957), Charnes et al (1978) was a group of people who introduced the DEA to the public. Assuming nonrandom mistakes, DEA used to calculate the relative technical efficiency of several units which have a similarity. This set similar unit was mentioned as decision making units (DMUs). At the first time, DEA was using to calculate the relative efficiency of some of non-profit organizations, such as schools and hospitals. Nowadays, DEA is also used for calculating the relative efficiency of some profit organizations. Comparing with the other firms in the same group, the firms were called efficient if the firms can produce a certain amount of output using less of input or the firms can produce more of output using a certain amount of input (Vincová, 2005). Shortly, in this study, the DEA will be used to evaluate the relative technical efficiency of several SMEs of stamped-batik located in Pekalongan, Solo, and Yogyakarta. DEA will be used to measure the relative technical efficiency of particular SME stamped batik by comparing it to SME(s) in the same group which was regarded as the efficient SME. This measurement is better than trying to compare the performance of several SMEs with statistical averages that may not be relevant to SMEs.

The rest of this paper is systematized as follows. The next session is a brief description about DEA methodology. This is followed by methodology of research which includes samples of research and explanation about several inputs and outputs used in this research. Then we present the results of calculating the relative technical efficiency of several targeted SMEs in the next section. Finally, we conclude the paper with a summary of findings and recommendation for future research. 


\section{Literature Review}

\subsection{Process of Making Batik}

In short, the process of making batik starts with preparation of clothes, dyes, waxes, chemical (natrium silicate, sodium carbonate), and the equipment related to batik making which are canting tool and stove. Then the process continues with applying the wax onto the fabric by using the canting tool. Then, the dying process takes over before boiled in water to remove the wax. The clothes then are being dried (Muaz, 2012).

Before applying the wax into the fabric, there are several activities that must be performed in the process of preparing the fabric so the fabric is ready for use. The process of preparing the fabric has two purposes. The first purpose, the process is intended to make sure that the wax stick to evenly to the surface and the wax will not crack when the fabric is dipped into dye. The second purpose of this process is intended to facilitate the penetration of the dye to those parts of the fabric which is not discovered. Failure to properly prepare the fabric will cause the resulting color becomes pale and uneven. The process of preparing the fabric is starting with washing the fabric to remove original starch. Then, the fabric is soaked in the vegetable oil. This process is called "ngloyor" or "ngetel". After soaking in the vegetable oil, the fabric is soaked again in the solution of of rice-straw ash and water in order to eliminate the excess oil. Currently, the solution of caustic soda is more chosen than the solution of of rice-straw ash and water because the solution of caustic soda works more quickly. After soaking in the solution of of rice-straw or the solution of caustic soda, the fabric is washed and dried, and then, the fabric is pounded with a heavy wooden mallet. This process is called "ngemplong" and by this process, the fabric will be smoothed out so the wax will be flowing evenly over it (Susanty et al, 2013; Sheares, 2012).

\subsection{Definition of SME}

There are so many small firms in Indonesia and the amount of small firms per capita in Indonesia is much higher than in most other countries (Kushnir et al., 2010). According to Law Number 20, 2008, small and medium-sized enterprise (SME) is an independent, productive economic enterprise, run by individual proprietor, or a venture which is not a subsidiary, owned, managed, and directly or indirectly part of bigger enterprises. Specifically, according to Law Number 20, 2008, small and medium-sized enterprise can be distinguished based on their total assets or based on total annual sales. Based on their total asset, small-sized enterprise are defined as those with net assets from IDR 50 million to IDR 500 million (land and buildings are excluded from their asset); whereas, medium-sized enterprises are defined as those with net assets from IDR 500 million to IDR 10 billion (land and buildings are excluded from their asset). Based on their total annual sales, small-sized enterprises are defined as those with total annual sales from IDR 300 million to IDR 2.5 billion; whereas, medium-sized enterprise are defined as those with total annual sales from IDR 2.5 to IDR 50 billion.

\subsection{Understanding Efficiency}

Nowadays, many organizations feel interest to conduct a study about their relative efficiency compare to their competitors. Efficiency has become an interesting topic of the research in a wide range of production activities. Efficiency index is calculated by dividing the total amount of output to the total amount of input and it is expressed as the percentage (Kengil et al, 2010). If there were more than one output and input, the efficiency index is calculated by dividing the sum weighted of outputs to sum weighted of inputs (Fare et al., 1994). Efficiency is the achievement with which an organization expenses their resources to create some outputs. In this case, efficiency is the degree to which the observed organization uses their resources to create some outputs with assumed quality, which is equivalent to the optimum use of resources to create some outputs with assumed quality. There were three categories can be used to assess the efficiency, i. e technical, allocative, and cost efficiency (Bhagavath, 2009).

The first category is technical efficiency. Technical efficiency is introduced by Farrell (1975) as the new measurement for efficiency. Technical efficiency is the most common efficiency concept and this concept utilizes the idea of the efficient production function. Technical efficiency delineates the capability to transform the inputs from the production unit into the outputs relative (Banihashem et al, 2013). Technical efficiency investigates how well the production process converts inputs into outputs. More specifically, technical efficiency delineates the capability to transform the inputs (such as the number of employees or machine, the working hour of the employees or machine, the amount of raw material used, etc.) into the outputs relative to best practice, so there is no leftovers of inputs in creating the specified amount of output with specified current technology (Banihashem et al, 2013).The organization with best 
practice will have $100 \%$ technical efficiency and the organization below the best practice will have the lower technical efficiency than the best practice, which value expressed as the percentage of the best organization (Bhagavath, 2009).

The second category is allocative efficiency. According to Farrell (1957), allocative efficiency can be stated as price efficiency. Specifically, allocative efficiency can be described as the capability of the organization to select the ideal mix of several inputs based on the data price of each input. Based on the assumption that the organization being inspected was already fully technically efficient, allocative efficiency refers to whether inputs (for a given level of output and a set of input prices) has been chosen to minimize the cost of production. In this condition, to measure allocative efficiency, someone needs to state every input in the form of relative to its price (see Atkinson \& Cornwell (1994); Green (1997); Kumbhakar (1991); Kumbhakar \& Tsionas (2005); Oum \& Zhang (1995)). It is very difficult in reality. Then, not different with technical efficiency, allocative efficiency is also stated as a percentage score. The organization with best practice in allocative efficiency will have scored $100 \%$. This organization has the capability to use a combination of input that would minimize the total cost. There is no relationship between the best of allocative efficiency with the best practice in engineering. The organizations with the best practice in the engineering context may be not have the best of allocative efficiency since this organization may be failing to use a combination of input, which is can be minimized the total cost of input (Bhagavath, 2009).

The last category is cost efficiency. Cost efficiency can be described as the combination of two types of efficiencies, i. e. technical and allocative efficiency. Technical efficiency talks about how well the production process converts inputs into outputs, whereas cost efficiency talks about how effective the choice of inputs based on data price of each input with the objective to minimize production costs. Based on this condition, an organization can only accomplish the cost efficiency if the organization can achieve both technical and allocative efficiency simultaneously. In other words, to achieve a $100 \%$ score in cost efficiency, the organization have to achieve a $100 \%$ score in technical and allocative efficiency (Bhagavath, 2009)

\subsection{Data Envelopment Analysis (DEA)}

DEA is one of the most recognized methods or approaches for calculating the relative efficiency between the Decision Making Units (DMUs). Based on the observed data, the DEA can calculate the relative efficiency of each of DMU, without formerly evaluating the specific equation for production system that mentions the relation between inputs and outputs. DEA can be used for evaluating the efficiency of each DMU even the unit measurement is different each other's. The DEA can also be used for calculating the relative efficiency of a combination of inputs/outputs that contains of at least two inputs and one output or two outputs and one input. It should be noted that a small data sample and the units of measurement consist of multiple inputs and outputs are not influencing the result of DEA (Christina \& George, 2009)

As a methodology, DEA has some strengths and weakness. The first strength, DEA can give detailed information about the efficiency of the firms and thus encourage a benchmarking approach for assessing the performance of the firms compared with the best practice. The second strength, the DEA is a flexible measurement tool. It is because, DEA does not need a parametric functional form to construct the frontier. In other words, DEA does not impose unnecessary restrictions on the functional forms which can very often cause a distortion of efficiency. DEA can be used for numbers of inputs and outputs variable and DEA doesn't need assumption about the functional relationship between input and output variable. In this case, it is no problem if someone uses the different measurement unit between the inputs and the outputs (Purwanto et al, 2014). Then some weakness of the DEA can be described as follows. Data as important information used by DEA need to be accurate and comprehensive otherwise the model will be faltering. Based on this condition, collecting data for the DEA is very difficult and may be consuming more time. The second weakness, DEA does not suitable for uncertainty situation. It is because the DEA is a deterministic approach. DEA only suitable for assessing the relative efficiency and not suitable when it is used to assess the absolute efficiency. Assessment of DEA result with the statistical method is very difficult. Besides that, weight and input resulted from DEA cannot interpret into economic value.

Farrell in 1957 is the person who introduces the basic DEA model. Later, this model is developed by Charnes et al (1978) and this model called Charnes-Cooper-Rhodes (CCR) model. The objective of this model is producing an efficient boundary based on the concept of Pareto optimum. The DMUs that provide the efficient boundary are chosen and are thus named Pareto-Optimal units or efficient DMUs. On the other hand, DMUs that do not lie on the efficient boundary are considered as relatively inefficient (Chien et al, 2003).

After 1978, another DEA model introduced by a number of researchers, i.e Banker, Charnes and Cooper or BCC from Banker et al (1984), Charnes-Cooper-Golany-Seiford-Stutz or CCGSS from Charnes et al. (1985), CharnesCooper-Wei or CCW from Charnes et al. (1986), Charnes-Cooper-Wei-Huang or CCWH from Charnes et al. (1989), Generalized Data Envelopment Analysis or GDEA from Yu et al (1996) and the other models have been established in 
succession (Sengupta, 1987; Yang et al, 1993; Zhang et al, 1996). Based on the development of its theory and application in numerous fields, DEA technique is shown to be effective in assessing and decision-making, particularly in the efficiency-measurement of production systems with multi-input and multi-output (Yang et al, 2000). This study only uses the BCC model to assess the Technical Efficiency because not all DMUs are working in optimal scale. There were some condition may cause a DMU to be not working at optimal scale, i.e. imperfect competition, limitations on finance etc. According to this situation, Banker et al (1984) recommended an extension of the Constant Return to Scale (CRS) DEA model to account of Variable Return to Scale (VRS) circumstances. The usage of the CRS specification while not all DMUs are working at optimal scale will result in measure of Technical Efficiency (TE), which is confounded by scale efficiencies (SE). So, the dissimilarities among CCR and BBC is the CCR version bases the assessment on CSR, while the BCC version is more flexible and allows VRS.

.Assume there are N DMUs. Each of DMU has $m$ input factors and $n$ output factor and each of DMU is denoted with $\mathrm{k}(1 \leq \mathrm{k} \leq \mathrm{N})$. Following CCR model, the efficiency $E_{k}$ of the $k_{t h} \mathrm{DMU}$, with inputs $X_{i k}$ (with $\mathrm{i}=1, \ldots, \mathrm{m}$ ) and outputs $Y_{r k}$ (with $r=1, \ldots . ., n$ ), can be computed as follows (Chien et al, 2003):

Maximize $E_{k}=\frac{\sum_{r=1}^{n} U_{r} Y_{r k}}{\sum_{i=1}^{m} V_{i} X_{i k}}$

under the following constraints:

$\frac{\sum_{r=1}^{n} U_{r} Y_{r j}}{\sum_{i=1}^{m} V_{i} X_{i j}} \leq 1 \quad j=1, \ldots \ldots \ldots, N$

$U_{r}, V_{i} \geq \varepsilon>0$

Where $\varepsilon$ is a non-archimedean quantity; $\varepsilon$ is a very small positive number. The CCR model is a fractional programming problem. To get an upper bound of 1 , the value of efficiencies of all of the DMUs $(j=1, \ldots \ldots, N)$ is limited by the above constraints. The $k^{\text {th }} \mathrm{DMU}$ is expressed as an efficient of DMU if it has a value of $E_{k}$ equivalent with 1 . The $k^{\text {th }}$ DMU is expressed as an inefficient DMU if it has a value of $E_{k}$ less than 1 . The variables $U_{r}$ with $r=1, \ldots, n$ and $V_{i}$ with $i=1, \ldots, m$ are the weights to be derived for each of the corresponding output and input factors while maximizing the efficiency of the $k^{\text {th }}$ DMU. In this case, DEA permits that individual DMUs can have their own value systems and structures, and thus, that individual DMUs can define their own weights. The CCR model can be converted into a linear programming model as follows (Chien et al, 2003):

Maximize $E_{k}=\sum_{r=1}^{n} U_{r} Y_{r k}$

Under the following constraints:

$\sum_{r=1}^{n} V_{i} X_{i k}=1$

$\sum_{r=1}^{n} U_{r} Y_{r j}-\sum_{r=1}^{n} V_{i} X_{i j} \leq 0, \quad j=1, \ldots \ldots \ldots, N$

$\mathrm{U}_{\mathrm{r},} \mathrm{V}_{\mathrm{i}} \geq \varepsilon \geq 0$

In general, the dual problem of the above model is solved for computational convenience and examining the slack variables (Chien et al, 2003).

\section{Methodology}

This methodology of research involves: (i) the selection of samples of research, and (ii) the selection of variables inputs and outputs.

\subsection{Sample}

Participant of this study consist of six owners of SMEs batik in Kauman Center (Pekalongan), four owners of SMEs batik in Laweyan Center (Solo), and six owners of SMEs batik in Wijirejo Center (Yogyakarta). Totally, there were sixteen SMEs who became a participant in this study. Then, this study conduct in-depth interviews and observations to the sixteen SMEs in order to investigate the resources which are used as input in the production process of making stamped batik and also to explore the output generated. This interview and observation were done in the period of July to September 2014. In this case, observation used as an approach to rise the validity of the study because observation can use to compare the data from interviews and from direct observation.

All SMEs who becomes a participant in this study were informed that the outcome of this study will be published, but their identity and their companies' identities will be kept confidential. All participants was also emphasized about benefit for being respondent of this study. All participation can perform benchmarking of their performance of the production process of making stamped-batik compared to other company's in the stamped-batik industry. 


\subsection{Inputs and Outputs}

In the DEA literature, there was lack commitment about the specification of input and output variables. Define and identify the quantity of inputs and output are the focal problem of DEA model (Sigala, 2004). Specifically, It is very complicated in DEA model to get the precise quantity of inputs and outputs because the wide-ranging nature of the business (Johnston \& Jones, 2004). Some input commonly used in earlier studies of DEA, i.e. the condition of capital, human, and environmental (Goldman, 1992). Furthermore, according to Donthu et al. (2005), the DEA model uses all factors associated with direct costs of undertaking the business as appropriate nominees for input variable. On the other hand, the DEA model uses the profit of the company as output variables; this variable should reveal the purpose or goals of the company.

The production process of making batik uses several inputs to produce stamped-batik. In this study, we use as input number of workers, amount of use of mori, wax, dyestuff, water, and fuel (LPG). Mori usage is calculated in meters/month, wax and dyestuff usage are calculated in grams/month, water usage is calculated in liters/month, and fuel usage is calculated in $\mathrm{kgs} / \mathrm{month}$. Then, in this study, we use a number of pieces of batik yielded in one month as output.

\section{Data Analysis}

Table 1 presents the data of the input and output from the production process of making batik in eighteen SMEs stamped-batik located in three region: Pekalongan, Solo, and Yogyakarta.

Table 1. Original data of the input and output from the production process of making stamped- batik

\begin{tabular}{|l|c|c|c|c|c|c|c|c|}
\hline Region & & \multirow{2}{*}{ SMEs } & $\begin{array}{c}\text { Output (pieces/ } \\
\text { month) }\end{array}$ & \multicolumn{6}{|c|}{ Input } \\
\cline { 4 - 8 } & Workers & $\begin{array}{c}\text { Mori } \\
\text { (meters/month) }\end{array}$ & $\begin{array}{c}\text { Wax (grams/ } \\
\text { month) }\end{array}$ & $\begin{array}{c}\text { Dyestuff } \\
\text { (grams/ month) }\end{array}$ & $\begin{array}{c}\text { Water (liters/ } \\
\text { month) }\end{array}$ & $\begin{array}{c}\text { Fuel (LPG) } \\
\text { (kgs/ month) }\end{array}$ \\
\hline Pekalongan & P1 & 7.350 & 40 & 15.000 & 500.000 & 45.000 & 40.000 & 240 \\
& P2 & 8.245 & 60 & 17.000 & 1.000 .000 & 60.000 & 31.500 & 600 \\
& P3 & 200 & 10 & 500 & 100.000 & 50.000 & 10.000 & 96 \\
& P4 & 400 & 25 & 1.400 & 100.000 & 20.000 & 22.500 & 300 \\
& P5 & 2.375 & 10 & 5.000 & 100.000 & 30.000 & 13.500 & 60 \\
& P6 & 1.000 & 7 & 2.500 & 50.000 & 11.000 & 5.000 & 99 \\
\hline Solo & S1 & 1.500 & 20 & 3.200 & 60.000 & 20.000 & 6.000 & 285 \\
& S2 & 4.000 & 17 & 10.000 & 100.000 & 24.000 & 15.000 & 425 \\
& S3 & 600 & 16 & 1.500 & 50.000 & 7.500 & 4.000 & 150 \\
& S4 & 625 & 5 & 1.400 & 50.000 & 8.000 & 150.000 & 62 \\
\hline Yogyakarta & Y1 & 2.624 & 20 & 5.525 & 500.000 & 55.000 & 350.000 & 375 \\
& Y2 & 850 & 20 & 1.800 & 100.000 & 26.000 & 200.000 & 180 \\
& Y3 & 90 & 5 & 200 & 20.000 & 6.000 & 3.000 & 100 \\
& Y4 & 950 & 8 & 2.000 & 160.000 & 15.000 & 10.000 & 150 \\
& Y5 & 700 & 10 & 1.540 & 150.000 & 16.500 & 150.000 & 240 \\
& Y6 & 1.000 & 8 & 2.250 & 150.000 & 20.000 & 30.000 & 200 \\
\hline
\end{tabular}

Each SME is considered as a DMU. Then, for the calculation of DMU's efficiency, Sistema Integrado De Apoio A Decisao (SIAD) ver 3.0 software (Angulo-Meza et al., 2005) was used and the result of this calculation can be seen in Table 2. The results in column two in Table 2 told us about the performance of efficiency of each SME in comparison with others. The result in column three in Table 2 told us about who will be the benchmarking units or the relevant reference unit for the corresponding SME. Based on this result, this study can give two recommendations for the SME. The first recommendation is about how much a specific unit (in this case SME batik) will be able to reduce its input while still being capable to produce the similar amount of output. The first recommendation doesn't concern about a technical or organizational problem. The second recommendation is a notification about which unit (in this case SME batik) that can serve as the benchmarking unit for an inefficient unit. The existence of benchmarking units make an inefficient unit (in this case SME batik) possible to conduct a study about production system that is more efficient than its own. Thus, this condition makes an inefficient unit likely to implement a more efficient method in organizing their process production (Mansoon, 2003). 
Table 2. Efficiency Score and Peers or The Benchmarking Units

\begin{tabular}{|l|c|c|c|c|}
\hline Region & SMES & \multicolumn{2}{|c|}{ Technical Efficiency } & Peers or The Benchmarking Units \\
\hline Pekalongan & P1 & 1,00 & Efficient & \\
& P2 & 1,00 & Efficient & \\
& P5 & 1,00 & Efficient & P2,P5,S1,S2 \\
& P6 & 0,90 & Inefficient & P1 \\
& P3 & 0,82 & Inefficient & P1 \\
\hline P4 & 0,58 & Inefficient & P1 \\
& S1 & 1,00 & Efficient & P1 \\
& S2 & 1,00 & Efficient & P1 \\
& S4 & 0,91 & Inefficient & P1 \\
& S3 & 0,82 & Inefficient & P1 \\
\hline Yogyakarta & Y1 & 0,97 & Inefficient & P1 \\
& Y4 & 0,97 & Inefficient & P1 \\
& Y2 & 0,96 & Inefficient & \\
& Y5 & 0,93 & Inefficient & Inefficient \\
& Y3 & 0,92 & Inefficient & \\
& Y6 & 0,91 &
\end{tabular}

The first present here the result of computing the technical efficiency scores. As seen in the Table 2, the mean of technical efficiency scores of all of the SMEs is 0.91 and the standard deviation is 0.11 . It is mean, overall, the surveyed SMEs have 9 percent in efficiency. There are eleven SMEs with technical efficiency score less than 1 and there are five SMEs with technical efficiency score equal to 1 . So, based on this condition, there are eleven inefficient SMEs and five efficient SMEs. All SMEs that have technical efficiency score equal to 1 are thus potential become the benchmarking units for corresponding SMEs. This SMEs also recommendations as 'standards' and 'envelop' for the other SMEs and, then, form the efficient boundary. In this case, the SME with code P2, P5, S1, and S2 are become the benchmarking units for SME with code P6. SME with code P1 is become the benchmarking unit for SMEs with code P3, $\mathrm{P} 4, \mathrm{~S} 4, \mathrm{~S} 3, \mathrm{Y} 1, \mathrm{Y} 2, \mathrm{Y} 3, \mathrm{Y} 4, \mathrm{Y} 5$, and $\mathrm{Y} 6$. The minimum technical efficiency score is 0.58 . This technical efficiency score belongs to SME with code P4. It means the SME with code P4 would have to reduce its input by 42 percent in order to become efficient.

When we compare the average amount of outputs and inputs between efficient SMEs and inefficient SMEs, it is observed that efficient SMEs expends less on the number of workers, amount of mori, wax, dyestuff, and fuel (LPG) than their inefficient corresponding SMEs. The efficient SMEs records more number of batik produced compared to inefficient corresponding SMEs. In this case, inefficient SMEs fail to convert effectively its worker and raw materials into a number of batik produced. Based on this condition, the inefficient SMEs necessities to examine the use their resource properly and find the minimum number of inputs required without impacting the quality of batik produced. In the next step, SIAD ver 3.0 software give recommendation about the number of input and output as the target for inefficient SMEs which is varied among SMEs according to the peers or the benchmarking units. This recommendation can be seen in Table 3 .

Table 3. Target Input and Output for Inefficient SMEs

\begin{tabular}{|c|l|c|c|c|c|c|c|}
\hline \multicolumn{2}{|l|}{ Output or Input } & P4 & P3 & P6 & Y1 & Y2 & Y5 \\
\hline \multirow{4}{*}{ Input } & Workers & 22 & 9 & 7 & 15 & 5 & 16 \\
\cline { 2 - 8 } & Mori (meters/month) & 1.400 & 500 & 2.500 & 5.525 & 1.540 & 1.800 \\
\cline { 2 - 8 } & Wax (grams/month) & 46.667 & 16.667 & 50.000 & 315.834 & 51.334 & 60.000 \\
\cline { 2 - 8 } & Dyestuff (grams/month) & 4.200 & 48.500 & 10.938 & 38.425 & 4.620 & 5.400 \\
\cline { 2 - 8 } & Water (liters month) & 3.733 & 1.333 & 5.000 & 335.267 & 4.107 & 4.800 \\
\cline { 2 - 8 } Output & Fuel (LPG) (kgs/month) & 278 & 88 & 99 & 287 & 25 & 152 \\
\cline { 2 - 8 } & Batik (pieces/month) & 686 & 245 & 1.114 & 2.707 & 754 & 882 \\
\hline
\end{tabular}




\begin{tabular}{|l|l|c|c|c|c|c|}
\hline \multicolumn{2}{|l|}{ Output or Input } & Y3 & Y4 & Y6 & S3 & S4 \\
\hline \multirow{5}{*}{} & Workers & 5 & 6 & 6 & 4 & 4 \\
\cline { 2 - 7 } & Mori (meters/month) & 200 & 2.000 & 2.250 & 1.500 & 1.500 \\
\cline { 2 - 7 } & Wax (grams/month) & 6.667 & 66.667 & 75.000 & 50.000 & 50.000 \\
\cline { 2 - 7 } & Dyestuff (grams/month) & 5.400 & 6.000 & 13.250 & 4.500 & 4.500 \\
\cline { 2 - 7 } & Water (liters month) & 534 & 5.334 & 24.000 & 4.000 & 4.000 \\
\cline { 2 - 7 } & Fuel (LPG) (kgs/month) & 97 & 118 & 164 & 24 & 24 \\
\cline { 2 - 7 } & Batik (pieces/month) & 98 & 980 & 102 & 735 & 735 \\
\hline
\end{tabular}

According to Table 1 and Table 3, to be efficient, P4 which have technical efficiency score 0,58 should reduce its worker and amount of wax, dyestuff, water, and LPG used in their production process of making batik. According to the benchmarking unit, P4 should reduce its worker by $12,00 \%$; from 25 workers to 22 workers. P4 should reduce the amount of wax used by 53,33\%; from 100.000 grams/month to 46,67 grams/month. P4 should also reduce the amount of dyestuff used by $79,00 \%$ (from 20.000 grams/month to 4.200 grams/month), the amount of water used by $83,41 \%$ (from 22.500 liters/month to 3.733 liters/month), and the amount of LPG used by $7,33 \%$ (from $300 \mathrm{kgs} / \mathrm{month}$ to 278 $\mathrm{kgs} /$ month). With a new input composition, P4 must able to increase their output production by $71,50 \%$; from 400 pieces batik/month to 686 pieces of batik/month. P3, P6, Y1, Y2, Y5, Y3, Y4, Y6, S3, and S4 also doing the similar thing to be efficient as the benchmarking unit.

\section{Conclusions}

This paper attempts to assess relative efficiencies in the production process of making stamped batik of 16 SMEs which is located in Pekalongan, Solo, and Yogyakarta. The origin of the study is based on the evidence that the efficiency in the production process of making stamped-batik can be enhanced through adequate allocation of resources in the production process. In this case, the inputs of the DEA model are the number of workers, amount of use of mori, wax, dyestuff, water, and fuel (LPG); whereas, the outputs of the DEA model are the number of pieces of batik yielded in one month. The result from DEA model assistances the SMEs to identify which SMEs from the same or different region that become their benchmarking or relevant reference unit, so the best practices conducted by the benchmarking unit can be applied to turn out to be an efficient one. DEA model also can calculate how much target input and output for the each inefficient SME to be enhanced so the inefficient SMEs can achieve best score as a referring unit. The certain SME can be used the DEA methodology offered in this study to calculate its own technical efficiency over time. In this case, certain SME can calculate its own technical efficiency based on existing data for several numbers of years and each year could be considered as a single DMU. Then, by doing such analysis, an SME would be able to quantitatively determine how well the performance of the enterprise over time.

Although the study conducted in in this paper is based on data collected by researcher from the three centers of stamped-batik in three regions, the methodology would advise a much larger geographical applicability on assessing the efficiency of the production process of making stamped-batik. In this study, only one output has been taken. More outputs can also be taken to make the study more exhaustive. Future research can also possible by taking customer satisfaction, the delivery efficiency as outputs. This study also has limitations due to the fact that this study does not capture the differences between the design of batik characteristics of each SMEs with regards to the input and operation condition. The next step for upcoming research is trying to examine the relationship between the variation of design of batik with the efficiency and conduct the statistical hypothesis testing about the significant relationship between variation of design of batik and efficiency..

\section{References}

Angulo-Meza, L, Neto, L. B., Soares de Mello, J. C. C. B., \& Gomes, E. G. (2005). Integrated system for decision support (SIAD Sistema Integrado de Apoio a Decisão): a software package for data envelopment analysis model. Pesquisa Operacional, 25 (3), 493-503.

Anwar, N., Supadi, Rahab, \& Afuan, L. (2013). Strategy to increase competitiveness of batik Banyumasan. International Journal of Business and Social Science, 4 (4), 305-311

Aribawa, Y. P. (2012). Analis tenaga kerja industri batik tulis Lasem di Kecamatan Pancur Kabupaten Rembang. Unpublished bachelor thesis, University of Muhamadiyah, Surakarta

Atkinson, S. E. \& Cornwell, C. (1994). Parametric estimation of technical and allocative inefficiency with panel data. International Economic Review 35(1), 231--243. 
Banihashem, Sh., Sanei, M, \& Mohamadian Manesh, Z. (2013). Cost, revenue and profit efficiency in supply chain. African Journal of Business Management, 7 (41), 4260-4267

Banker, R. D., Charnes, A., \& Cooper, A. A. (1984). Some models for estimating technical and scale inefficiencies in data envelopment analysis. Management Science, 9, 1078-092

Bhagavath, V. (2009). Technical efficiency measurement by data envelopment analysis: an application in transportation. Alliance Journal of Business Research. Retrieved January 02, 2015, from http://ajbr.org/archives.htm

Budiono, G., \& Vincent, A. (2010). Batik industry of Indonesia: the rise, fall, and prospects. Studies in Business and Economics, 5(3), 156-170.

Charnes, A., Cooper, W. W., \& Rhodes, E. (1978). Measuring the efficiency of decision making units. European Journal of Operational Research, 2(6), 429-444.

Charnes, A., Cooper, W. W, \& Wei, Q.L. (1986). A semi-infinite multicriteria programming approach to data envelopment analysis with infinitely many decision-making units (Report CCS 551), Texas, Austin, University of Texas, Center for Cybernetic Studies

Charnes, A., Cooper, W. W., \& Rhodes, E. (1978). Measuring the efficiency of decision making units. European Journal of Operational Research, 2 (4), 429-444.

Charnes, A., Cooper, W. W., Golany, B., Seiford, L, \& Stutz, J. (1985). Foundation of data envelopment analysis for pareto-koopmans efficient empirical production. Journal of Econometrics (Netherlands), 30 (1), 91 -107.

Charnes, A., Cooper, W. W., Wei, Q. L., \& Huang, Z. M. (1989). Cone ratio data envelopment analysis and multi-objective programming. International Journal of Systems Science, 20 (7), 1099-1118

Chien, C.F., Lo, F. Y., \& Lin, J.T. (2003). Using DEA to measure the relative efficiency of the service center and improve operation efficiency through reorganization. IEEE Transactions on Power Systems, 18 (1), 366-373

Christina, B., \& George, H. (2009). The use of the DEA method for simultaneous analysis of the interrelationships among economic growth, environmental pollution and energy consumption. International Journal of Economic Sciences and Applied Research, 2 (2), $65-86$

Darmansyah \& Soebagyo, D. (2010). Stimulus ekspor terhadap kinerja perusahaan-perusahaan batik. Jurnal Ekonomi Pembangunan, 11(2), 254-265

Donthu, N., Hershberger, E. K, \& Osmonbekok, T. (2005). Benchmarking marketing productivity using data envelopment analysis. Journal of Business Research, 58, 1474-1482.

Fare, R., Grosskopf, S., \& Lovell, C. (1994), Production frontiers, Cambridge: Cambridge University Press

Farrell, M. J. (1957). The measurement of productive efficiency. Journal of the Royal Statistical Society, Series A, 120 (3), $253-290$.

Goldman, A. (1992). Evaluating the performance of Japanese distribution System. Journal of Retailing, 68 (1), 11-39.

Greene, W. (1997). Frontier production functions. In M. H. Pesaran \& P. Schmidt (Ed.), Handbook of applied econometrics, vol. II (pp. 91-166), Blackwell Publishers.

Gunaryo, Sudarman, D., Wibowo, H. B., \& Ambarita P. (2008). Pengembangan ekonomi kreatif Indonesia 2025: rencana pengembangan ekonomi kreatif Indonesia 2009-2015. Jakarta, Indonesia: Ministry of Trade of The Republic of Indonesia, Report.

Hasanudin. (2001). Batik pesisiran: melacak pengaruh etos dagang santri pada ragam hias batik. Bandung, Indonesia: Kiblat Buku Utama

Hayati, A. (2007, November). Pengaruh faktor sosial, ekonomu dan budaya terhadap kewirausahaan batik Garutan. Paper presented at Regional Asia-Pasific Workshop on Women Entrepreneurship Development, Bali, Indonesia.

Iriani, A., \& Priyanto, S. H. (2013). Modeling of employee relationship in SME batik: case study of Windasari batik. Asean Journal of Management Sciences \& Eucation, 2 (4), 122-135

Iriani, A., \& Priyanto, S.H. (2013). Modeling of employee relationship in SME batik: case study of Windasari Batik. Asian Journal of Management Sciences and Education, 2(4), 22-35

Johnston, R., \& Jones, P. (2004). Service productivity towards understanding the relationship between operational and customer productivity. International Journal of Productivity and Performance Management, 53 (3), 201-213.

Kengil, B. C, Gökmen, N., \& Tozan, H. (2010). Efficiency measures in the health services with DEA- an overview. Journal of Naval Science and Engineering, 6 (1), 1-14

Kumbhakar, S. C. (1991). The measurement anddecomposition of cost-inefficiency: The translog cost system. Oxford EconomicPapers, New Series 43(4), 667-683.

Kumbhakar, S. C., \& Tsionas, E. G. (2005). Measuring technical and allocative inefficiencyinthe translogcost system: a Bayesian approach. Journal of Econometrics 126, 355-384.

Kushnir, K., Mirmulstein, M. L, \& Ramalho, R. (2010). Micro small and medium term enterprise around the world: how many are there and what affects the count?. World Bank and IFC MSME Country Indicators.

Mansson, J. (2003). How can we use the result from a DEA analysis? Identification of firm relevant reference unit. Journal of Applied Economics, VI(1), 157-175

Meutia. (2013). Improving competitive advantage and business performance through the development of business network, adaptability of business environment and innovation creativity: an empirical study of batik small and medium enterprises (SME) in Pekalongan, Central Java, Indonesia. Aceh International Journal of Social Sciences, 2 (1), 11 - 20

Muaz, M. (2012). Design and development of semi automatic canting tool (body design and mechanism). Unpublished bachelor thesis, University Malaysia Pahang, Pahang. 
Nurdalia, I. (2006). Kajian dan analisis peluang penerapan produksi bersih pada usaha kecil batik cap (studi kasus pada tiga usaha industri kecil batik cap di pekalongan). Unpublished master thesis, University of University, Semarang, Indonesia.

Oparinde, S. S. (2012). Batik as a cultural identity of the Yoruba: hand colouring techniques and applications, possibility of adaptations. Journal of Arts, Science \& Commerce, 3, 31-41

Oum, T. H., \& Zhang, Y. (1995). Competition and allocative efficiency: The case of the U.S. telephone industry. The Review of Economics and Statistics 77(1), 82-96.

Purwanto, Manongga, D., \& Ineke Pakereng, M. A. (2014). Efficiency of small-and medium-sized tofu enterprises (SME) in Salatiga using data envelopment analysis (DEA). International Journal of Computer Applications, 91(12), 44-50.

Rayeni, M. M., \& Saljooghi, F. (2012). Equitable allocation of fixed costs and its effect on technical and cost efficiency: Case study in universities. African. Journal Bussiness Management. 6(4), 1263-1269

Sengupta, J. K. (1987). Data envelopment analysis for efficiency measurement in the stochastic case. Computers and Operations Research, 14 (2), 117- 129.

Sheares, C. A. (2009). The batik patterning technique in Southeast Asia. The Heritage Journal, 4, 97-129

Sigala, M. (2004). Using data envelopment analysis for measuring and benchmarking productivity in the hotel sector. Journal of Travel and Tourism Marketing, 6 (2/3), 39-60.

Susanty, A., Puspitasari D., Rinawati, D. I., \& Monika T. (2013). The priority of alternative on-site recovery application as cleaner production practice in SME Batik in Central of Java, Indonesia. Global Perspective on Engineering Management, 2 (3), $154-164$

Vincová, I. K. (2005). Using DEA models to measure efficiency", BIATEC, XIII (8), 2005, 24-28

Yang, Y., Ma, B., \& Koike, M. (2000). Efficiency-measuring DEA model for production system with k independent subsystems. Journal of the Operations Research Society of Japan, 43 (3), 343-354

Yang, Y.S., Li, L., \& Gao, H. L. (1993). DEA model for grey systems and its application. In Proceeding of AMSE Conference Modeling, Simulation \& Control (pp. 1577-1587). Hefei, China: USTC Press

Yu, G., Wei, Q. L., \& Brockett, P. (1996). A generalized data envelopment analysis model: a unification and extension of existing methods for efficiency analysis of decision-making Units. Annals of Operation Research, 66 (4), 47-92.

Zhang, K.Y, Yang, Y. S., \& Li, L. H. (1996). Data envelopment analysis model with fuzzy Numbers. In Proceedings of the Third ChinaJapan International Symposium on Industrial Management (pp. 431-436). Beijing, China: International Academic Publishers 